\title{
PERFORMANCE AND BEHAVIOR OF DAIRY CALVES FED DIETS CONTAINING MILK AND CITRIC FLAVOR AGENTS
}

\author{
Desempenho e comportamento de bezerros leiteiros alimentados com dietas contendo \\ agentes de flavor lácteo e cítrico
}

\author{
Silvane Barcelos Carlotto ${ }^{1}$, Clair Jorge Olivo², Julio Viégas ${ }^{2}$, David Arthur Stiles ${ }^{3}$, Alexandre Mossate Gabbi ${ }^{1}$, \\ Karen Döering Brustolin', Pablo Santini Charão ${ }^{1}$, Grasiela Rossarolla ${ }^{4}$, Magnos Ziech, \\ Lilian Elgalise Techio Pereira ${ }^{4}$, Luciene Fernanda Scaravelli ${ }^{4}$
}

\begin{abstract}
While young ruminants prefer milk aroma and researches about this theme are being developed, the use of citric aroma, very appetized for older ruminants, are low utilized to young animals. This work aims to compare the influence of milk and citric flavor agents on the diets of nursing dairy calves. In this trial, 12 animals of Holstein breed were distributed in a randomized block design with four treatments (concentrate without flavor agent, concentrate with milk flavor or citrus flavor, and concentrate with milk plus citrus flavor agent) and three repetitions. The parameters evaluated were: concentrate dry matter intake (CDMI), hay dry matter (HDMI), milk dry matter intake (MDMI) and total dry matter intake (TDMI), average weight gain (ADWG), feed conversion (FC), initial (IBW) and final body weight (FBW), initial thoracic perimeter (ITP) and final thoracic perimeter (FTP), initial abdominal perimeter (IAP) and final abdominal perimeter (FAP), initial withers height (IWH) and final withers height (FWH) and animal behavior. The CDMI, HDMI and TDMI, as well as IBW, FBW, ITP, FTP, IAP, FAP, IWH and FWH did not show differences $(\mathrm{P}>0.05)$. The averages daily gain and feed conversion showed no differences, with means of $0.55 \mathrm{~kg} / \mathrm{animal}$ and 2.09 , respectively. The diets did not affect animal behavior parameters $(\mathrm{P}>0.05)$.
\end{abstract}

Index terms: Dry matter intake, palatability, performance, behavior, flavour.

\section{RESUMO}

Enquanto ruminantes jovens preferem aroma de leite e pesquisas sobre este tema são desenvolvidas, o uso de aroma cítrico, muito apreciado por ruminantes adultos, é pouco utilizado para animais jovens. Portanto, com este trabalho visou-se comparar a influência de aromas lácteo e cítrico nas dietas de bezerros na fase de aleitamento. Neste experimento foram utilizados 12 animais da raça Holandesa, distribuídos em um delineamento de blocos ao acaso, com quarto tratamentos (concentrado sem palatabilizante e concentrado com palatabilizante lácteo, cítrico e lácteo mais cítrico) e três repetições. Foram avaliados o consumo de matéria seca do concentrado (CMSC), do feno (CMSF), do leite (CMSL) e do total (CMST), ganho médio diário (GMD), conversão alimentar (CA), peso inicial (PI) e final (PF), perímetro torácico inicial (PTI) e final (PTF), perímetro abdominal inicial (PAI) e final (PAF), altura de cernelha inicial (ACI) e final (ACF) e o comportamento animal. O CMSC, CMSF e CMST não apresentaram diferenças da mesma forma que as mensurações de PI, PF, PTI, PTF, PAI, PAF, ACI e ACF. O ganho médio diário e a conversão alimentar não foram diferentes, obtendo-se médias de 0,55 kg/animal e 2,09, respectivamente. As dietas também não influenciaram os parâmetros de comportamento animal $(\mathrm{P}>0,05)$.

Termos para indexação: Consumo de matéria seca, palatabilidade, desempenho, comportamento, flavorizantes.

(Received in march 22, 2005 and approved in october 25, 2006)

\section{INTRODUCTION}

The main objectives of animal production are profit and high quality feedstuffs, causing a minimum negative impact on animal welfare and the environment (WEBERNIELSEN \& BERGFELD, 2003). In dairy farms, the objective is to obtain the maximum milk yield with a reduction in the nursing time of calves. More economic systems of calf breeding, with the adoption of improved feeding management practices, may make possible greater feed efficiency for replacement heifers as well as male calves destined for meat production.

Nevertheless, when calves are born, their digestive tract do not present morphological characteristics equal to that of an adult ruminant yet. The manipulation and knowledge about microbes, digestive juices and their functions in pre-ruminants calves is necessary to utililize the nutrients with greater efficiency (GUILLOTEAU et al.,

'Zootecnista, M.Sc., Departamento de Zootecnia da Universidade Federal de Santa Maria/UFSM - Campus Universitário - $97105-900$ - Santa Maria, RS - Brasil.

${ }^{2}$ Zootecnista, Dr., Universidade Federal de Santa Maria/UFSM - Campus Universitário - 97105-900 - Santa Maria, RS - Brasil - clairo@ccr.ufsm.br ${ }^{3}$ Nutricionista, PhD, Professor Associado do Departamento de Agricultura - Western Kentucky University - Bowling Green - USA.

${ }^{4}$ Acadêmicos de Zootecnia do Departamento de Zootecnia da Universidade Federal de Santa Maria/UFSM - Campus Universitário - $97105-900$ Santa Maria, RS - Brasil. 
1994). The intake of solid feedstuffs will accelerate the process of the development of reticulum-rumen system in calves (CHURCH, 1988).

The use of additives in animal production has as objective to improve animal performance, with better development in a shorter time. Flavor agents should contribute for a higher feed intake, since the cattle have sensibility to different taste and aromas, it might be reflected in better performance and body development (NOMBEKELA et al., 1994). The palatability is determined by foods characteristics, which cause a response in animal senses such as vision, smell, touch and taste, resulting in an appetite more or less developed for specific foods (CHURCH, 1988; MATTHEWS, 1983). Also Baumont (1996) observed that the feed palatability complex is part of physical (plant structure, defense mechanism) and chemical (taste, smell) characteristics, which determine the animal preference. Ruminants prefer feeds, which physical characteristics allow a faster/ greater ingestion, due to rumen digestion and rate of passage.

Some researches demonstrate different preferences of both young and older ruminants about some flavor agents. While young ruminants prefer milk taste and aroma, older ruminants, such as dairy cows prefer citric taste and aroma. This experiment aims to compare milk and citric flavor agent added to concentrate for nursing dairy calves.

\section{MATERIALS AND METHODS}

The experiment was conducted in the Dairy Sector of the Department of Animal Science, Universidade Federal de Santa Maria, Brazil, from April $11^{\text {th }}$ to June $6^{\text {th }}, 2003$. Twelve male dairy calves, Holstein breed, put on trial after a post-colostral period (four days old) and weaned with fifty-six days old, were used.

The calves were fed with the concentrate containing different flavor agents, using the following treatments: T0 - control (standard concentrate) without addition of flavor agent; $\mathrm{T} 1$ - standard concentrate + milk flavor agent $(300 \mathrm{~g}$
MFA/ton. concentrate); T2 - standard concentrate + citrus flavor agent (300g CFA/ton. concentrate); T3 - standard concentrate + citrus flavor agent plus milk flavor agent (150g MFA $+150 \mathrm{CFA} /$ ton. concentrate). The addition of flavor agent in the concentrate was made in a mechanical mixer, shaked for, approximately, 10 minutes to guarantee efficient mixture of the additive and concentrate. The standard concentrate composition was soybean meal, corn grain and wheat bran. The milk flavor agent attempted to reproduce cow's milk aroma and was composed of a white fine powder with an immediate aromatic perception of milk, while the citrus flavor agent produced an aroma and taste of orange, also supplied as a white fine powder. The vehicle utilized by the two flavor agents was silica oxide $\left(\mathrm{SiO}_{2}\right)$ and calcium carbonate $\left(\mathrm{CaCO}_{3}\right)$.

From birth up to the fourth day, the calves received $4 \mathrm{~L}$ of colostrum, in two daily feedings. From the fifth day on, they received $4 \mathrm{~L}$ of whole milk, divided in two feedings, at 7:30 a.m. and 5:30 p.m., during all experimental time. After first week old, calves received water and concentrate $a d$ libitum up to wean time ( $56^{\text {th }}$ days old). Alfalfa hay was introduced into the diet from the third week and were offered an amount of concentrate and hay up to a surplus of 10 to $15 \%$ of offered feed consumed. The nutritional value of the diets is presented in Table 1.

Total feed intake was estimated by calculating the difference between the amount of concentrate and hay offered and the orts taken daily. The intake was evaluated using the following parameters: concentrate dry matter intake (CDMI), hay dry matter intake (HDMI), milk dry matter intake (MDMI) and total dry matter intake (TDMI). Feed conversion was calculed from TDMI and total weight gain during the experimental period (56 days). The body development was evaluated by measuring thoracic and abdominal perimeters with measuring tape; wither height were measured using an adapted ruler and live weight was obtained in a mechanical scale. Evaluations were conducted weekly during all experimental periods before feeding in the morning period. In the evaluation of animal behavior, the

TABLE 1 - Nutritional value of diet offered to dairy calves in the experimental period (dry matter basis).

\begin{tabular}{lcccccc}
\hline \multicolumn{1}{c}{ Item } & $\begin{array}{c}\text { Dry matter } \\
(\boldsymbol{\%})\end{array}$ & $\begin{array}{c}\text { Crude protein } \\
(\boldsymbol{\%})\end{array}$ & $\begin{array}{c}\mathbf{N D F}^{\mathbf{1}} \\
(\boldsymbol{\%})\end{array}$ & $\begin{array}{c}\text { Fat } \\
(\boldsymbol{\%})\end{array}$ & $\begin{array}{c}\text { Ash } \\
(\boldsymbol{\%})\end{array}$ & $\begin{array}{c}\text { TDN }^{2} \\
(\boldsymbol{\%})\end{array}$ \\
\hline Whole milk & 12.00 & ---- & ---- & ---- & ---- & ---- \\
Concentrate & 86.65 & 19.18 & 41.60 & 9.96 & 6.41 & 78.41 \\
Hay & 86.62 & 20.18 & 18.09 & 6.46 & 7.97 & 62.10 \\
\hline
\end{tabular}

${ }^{1}$ Neutral Detergent Fiber; ${ }^{2}$ Total Digestible Nutrients, calculated.

Ciênc. agrotec., Lavras, v. 31, n. 3, p. 889-895, maio/jun., 2007 
animals were observed during a period of 12 hours (720 minutes), from 6 a.m. to 6 p.m., at each five minutes. During the experimental period, four evaluations (April 25 ${ }^{\text {th }}$; May $9^{\text {th }}$; May $23^{\text {rd }}$ and June $6^{\text {th }}, 2003$ ) were made. Time of ingestion of solid feeds (concentrate, hay) and liquid (milk, water), idleness (stood up and laid down), rumination (stood up and laid down) and playing activities were observed.

The experimental design was randomized blocks, in which the blocking factor was the calves birth order. The data were analysed by ANOVA and Tukey's Test at $5 \%$ probability utilizing SAS statistical program (SAS INSTITUTE, 1997). The statistical model adopted was as follows: $Y_{i j}=\mu+\tau_{i}+\beta_{j}+\varepsilon_{i j}$, where $i$ represent the repetitions index; $j$ is the treatments index; $Y_{i j}$ represents the dependent variables; $\mu$ is the general mean; $\tau_{i}$ effect of treatment; $\beta_{j}$ is the effect of blocks and $\mathrm{e}_{\mathrm{ij}}$ represents the residue.

\section{RESULTS AND DISCUSSION}

The means of concentrate, hay, milk and total dry matter intake and feed conversion, which was found during the experimental period, are shown in Table 2. No differences $(\mathrm{P}>0.05)$ among treatments were observed. These results agree with the conclusions of Chandler et al. (1968), Cheeke (1991), Miller et al. (1958) and Shuh \& Wegner (1979). According to these authors, the use of flavor agents did not contribute to increased feed ingestion. The response obtained contest those of Albright (1993) who noted a tendency of increasing the intake with the use of flavor agents and with results observed by Lucci (1989), who observed an increased intake of diets with apple and milk flavor agents.

Chua et al. (2002) and Hafez \& Dyer (1972) mentioned a probable influence of flavoring agents in increasing intake, when the animals are isolated in individual pens. Howeverer, this comportment did not was observed in this research.

The use of basic feeds of excellent quality, with 20 $\%$ crude protein $(\mathrm{CP})$ and $80 \%$ total digestible nutrients (TDN), and the use of alfalfa hay, might interfere in a possible effect of flavor agents on the solid feeds intake. A greater variation in the quality of feed ingredients might occur by using flavoring agents over a greater period of time, in terms of feed intake by calves. Atwood et al. (2001) mentioned the preference of beef calves for feeds with high content of protein or energy, and this could explain why there were no significant differences among diets. Cheeke (1991) noted a possibility of flavor agents affecting and increasing the intake of poor quality feeds. Notwithstanding, some authors (LUCCI, 1989; MORRILL \& DAYTON, 1974; NOMBEKELA et al., 1994) reported that the use of flavor agents increased intake in good quality feeds, which was not confirmed in the present experiment.

There was a major variability in concentrate intake when compared with hay intake. This behavior has been observed previously by Severo (1995) and Vasconcelos (1996), who compared installations and liquid diets, observed coefficients of variation of 43.6 e $12.0 \%$, respectively, for concentrate and hay intake. There was a more uniform intake for hay as demonstrated by a lower coefficient of variation (Table 2). This condition was also observed by León (1994) in similar work, also using alfalfa hay, with a coefficient of variation (with intake) of $5.42 \%$. Severo (1995) and Vasconcelos (1996) observed coefficients of variation of 20.5 e $45.1 \%$ by using the same feed management of Bermudagrass and millet hay, respectively.

TABLE 2 - Concentrate dry matter intake (CDMI), milk dry matter intake (MDMI), hay dry matter intake (HDMI), total dry matter intake (TDMI) and feed conversion (FC) of calves, in $\mathrm{kg}$, submitted to different diets.

\begin{tabular}{lccccccc}
\hline & \multicolumn{3}{c}{ Treatment } & & & \\
\cline { 2 - 5 } Item & Control & $\begin{array}{c}\text { Control } \\
+ \text { +MFA }\end{array}$ & $\begin{array}{c}\text { Control } \\
+ \text { +CFA }\end{array}$ & $\begin{array}{c}\text { Control + } \\
\text { MFA + CFA }\end{array}$ & $\begin{array}{c}\text { Average } \pm \text { error } \\
\text { standard }\end{array}$ & $\begin{array}{c}\text { Value of } \\
\text { P }\end{array}$ \\
\hline CDMI & 30.7 & 29.4 & 21.6 & 28.9 & $27.6 \pm 5.68$ & 0.643 \\
MDMI $^{1}$ & 26.8 & 26.8 & 26.8 & 26.8 & 26.8 & - \\
HDMI & 8.29 & 8.70 & 8.43 & 10.6 & $9.02 \pm 1.32$ & 0.687 \\
TDMI & 65.8 & 65.0 & 56.9 & 66.5 & $63.5 \pm 6.27$ & 0.685 \\
FC & 2.03 & 2.01 & 2.05 & 2.28 & $2.09 \pm 0.23$ & 0.172 \\
\hline
\end{tabular}

$(\mathrm{P}<0.05) ;{ }^{1}$ Estimated dry matter $=120 \mathrm{~g} / \mathrm{l} ; \mathrm{MFA}=$ milk flavor agent; $\mathrm{CFA}=$ citrus flavor agent. 
The average daily intake, through the experimental period, was $498 \mathrm{~g}$ of concentrate/calf. This value was superior to the results obtained by Vasconcelos (1996) of 342g/calf/ day, who compared different diets, installations and year with seasons. Susin et al. (1988) observed a concentrate dry matter intake of $532 \mathrm{~g} / \mathrm{calf} /$ day, in weaned calves at 45 days.

No significative effect $(\mathrm{P}>0.05)$ was observed among treatments for feed conversion. The general average observed (2.09) was higher than the values obtained by León (1994) and Severo (1995) with 1.79 and 1.76 respectively, but similar to values (2.11) observed by Vasconcelos (1996).

In Table 3, the means of live weight $(\mathrm{kg})$, thoracic perimeter, abdominal perimeter and wither height $(\mathrm{cm})$, at the start and the end of the experimental period, and the estimate changes in these parameters for all treatments are shown. It can be seen, there were no significant differences among the treatments.

It was observed that the mean of initial weight of animals, $42.4 \mathrm{~kg}$, was higher in comparison with other works (LEÓN, 1994; SEVERO, 1995; VASCONCELOS, 1996), developed in the same region, with male calves of Holstein breed of individual initial weight varying from 36.3 to 37.3 $\mathrm{kg}$. The data demonstrate a crescent linear effect ( $\mathrm{Y}=$
$34.8+4.47 \mathrm{x} ; \mathrm{R}^{2}=0.58 ; \mathrm{P}<.0001$ ) for average weight gain. Similar data were obtained by Severo (1995), with $\mathrm{Y}=$ $36.19+0.63 x ; R^{2}=0.85$.

The average daily gain (545 g/animal/day) was superior to that ( $452 \mathrm{~g}$ ) observed by Liziere et al. (2002), who conducted work with similar periods of weaning and feed management. Schalch et al. (2001) observed values of average daily gain of $453 \mathrm{~g} / \mathrm{animal} / \mathrm{day}$ and variation of the measurement of wither height and thoracic perimeter up to weaning time of 10.0 and $14.4 \mathrm{~cm}$, respectively. In the present work, the variations of wither height and thoracic perimeter were 10.6 and $18.6 \mathrm{~cm}$ at weaning time, respectively.

In Table 4 , it is showed results of time spent by calves in each activity in all treatments. The analyses demonstrate that no significant differences were found among treatments.

A probable effect of flavor agents, which might be observed by higher atractivity of calves for feedstuffs that contained these additives, as well as the frequency and amount consumed, was not observed. Although ruminants have a great sensibility to feel different smells and tastes, the research demonstrated that the use of flavor agent did not influence the feeding behavior of animals.

TABLE 3 - Initial (ILW) and final liveweight (FLW), variation of liveweight (VLW), average daily weight gain (ADWG), feed conversion (FC), in kg, initial (ITP) and final thoracic perimeter (FTP), variation of thoracic perimeter (VTP), initial (IAP) and final abdominal perimeter (FAP), variation of abdominal perimeter (VAP), Initial (IWH) and final wither height $(\mathrm{FWH})$, variation of wither height $(\mathrm{VWH})$, in $\mathrm{cm}$, of Holstein calves submitted to different diets.

\begin{tabular}{lrrrrrr}
\hline \multirow{2}{*}{ Item } & Control & $\begin{array}{c}\text { Control }+ \\
\text { MFA }\end{array}$ & $\begin{array}{c}\text { Control }+ \\
\text { CFA }\end{array}$ & $\begin{array}{c}\text { Control + } \\
\text { MFA+CFA }\end{array}$ & $\begin{array}{c}\text { Average } \pm \\
\text { error standard }\end{array}$ & Value of P \\
\cline { 2 - 5 } ILW & 40.8 & 40.8 & 41.1 & 47.0 & $42.4 \pm 2.47$ & 0.306 \\
FLW & 73.5 & 73.8 & 68.6 & 76.0 & $73.0 \pm 4.87$ & 0.755 \\
VLW & 32.6 & 33.0 & 27.5 & 29.0 & $30.5 \pm 2.77$ & 0.524 \\
ADWG & 0.58 & 0.58 & 0.49 & 0.51 & $0.54 \pm 0.04$ & 0.526 \\
ITP & 82.0 & 82.0 & 83.6 & 86.3 & $83.5 \pm 1.88$ & 0.393 \\
FTP & 104.0 & 101.8 & 99.3 & 103.3 & $102.1 \pm 3.18$ & 0.742 \\
VTP & 22.0 & 19.8 & 15.6 & 17.0 & $18.6 \pm 3.24$ & 0.344 \\
IAP & 79.0 & 82.0 & 80.0 & 85.3 & $81.5 \pm 1.77$ & 0.157 \\
FAP & 104.0 & 105.3 & 98.6 & 107.6 & $103.9 \pm 3.46$ & 0.382 \\
VAP & 25.0 & 23.3 & 18.6 & 22.3 & $22.3 \pm 3.48$ & 0.572 \\
IWH & 77.0 & 78.3 & 78.5 & 78.0 & $77.9 \pm 1.29$ & 0.845 \\
FWH & 89.0 & 89.1 & 86.6 & 89.5 & $88.5 \pm 1.66$ & 0.636 \\
VWH & 12.0 & 10.8 & 8.16 & 11.5 & $10.6 \pm 1.01$ & 0.827 \\
\hline
\end{tabular}

$(\mathrm{P}<0.05) ; \mathrm{MFA}=$ milk flavor agent; $\mathrm{CFA}=$ citrus flavor agent.

Ciênc. agrotec., Lavras, v. 31, n. 3, p. 889-895, maio/jun., 2007 
TABLE 4 - Time spent, in minutes, for solid intake (concentrate, hay), liquid intake (whole milk, water), rumination (Stood up, Laid down) and idleness (Stood up, Laid down) of dairy calves submitted to different diets.

\begin{tabular}{|c|c|c|c|c|c|c|}
\hline \multirow[b]{2}{*}{ Item } & \multicolumn{4}{|c|}{ Treatment } & \multirow[b]{2}{*}{$\begin{array}{l}\text { Average } \pm \text { error } \\
\text { standard }\end{array}$} & \multirow{2}{*}{$\begin{array}{c}\text { Value of } \\
\qquad P\end{array}$} \\
\hline & Control & $\begin{array}{l}\text { Control } \\
+ \text { MFA }\end{array}$ & $\begin{array}{l}\text { Control } \\
+ \text { CFA }\end{array}$ & $\begin{array}{c}\text { Control } \\
+\mathrm{MFA}+\mathrm{CFA} \\
\end{array}$ & & \\
\hline \multicolumn{7}{|l|}{ Intake } \\
\hline - Concentrate & 46.7 & 45.0 & 44.0 & 51.1 & $46.7 \pm 0.47$ & 0.287 \\
\hline - Hay & 90.6 & 82.8 & 68.9 & 86.7 & $82.2 \pm 0.86$ & 0.369 \\
\hline - Total & 137.2 & 127.8 & 112.9 & 137.8 & $128.9 \pm 1.96$ & 0.098 \\
\hline \multicolumn{7}{|l|}{ Intake } \\
\hline - Whole milk & 10.0 & 10.0 & 10.0 & 10.0 & 10.0 & - \\
\hline - Water & 5.60 & 5.00 & 8.90 & 11.7 & $7.8 \pm 0.01$ & 0.114 \\
\hline - Total & 15.6 & 15.0 & 18.9 & 21.7 & $17.8 \pm 0.04$ & 0.114 \\
\hline \multicolumn{7}{|l|}{ Rumination } \\
\hline - Stood up & 8.30 & 3.30 & 5.60 & 2.8 & $5.0 \pm 0.01$ & 0.203 \\
\hline - Laid down & 98.9 & 93.9 & 95.0 & 97.8 & $96.4 \pm 2.26$ & 0.995 \\
\hline - Total & 107.2 & 97.2 & 100.6 & 100.6 & $101.4 \pm 2.57$ & 0.971 \\
\hline \multicolumn{7}{|l|}{ Idleness } \\
\hline - Stood up & 208.9 & 206.7 & 181.0 & 202.8 & $199.8 \pm 5.65$ & 0.679 \\
\hline - Laid down & 251.1 & 273.3 & 306.7 & 257.2 & $272.1 \pm 13.3$ & 0.696 \\
\hline - Total & 460.0 & 480.0 & 487.7 & 460.0 & $471.9 \pm 17.4$ & 0.796 \\
\hline
\end{tabular}

$(\mathrm{P}<0.05) ; \mathrm{MFA}=$ milk flavor agent; CFA = citrus flavor agent. Time of watch: 6 a.m. at 6 p.m. $(720$ minutes $)$.

The results were similar to those observed by other researchers (CHANDLER et al., 1968; MILLER et al., 1958; MORRILL \& DAYTON, 1974; SHUH \& WEGNER, 1979). The animals of the Control + CFA treatment showed higher concentrate intake. However, comparing the intake based on the percentage of live weight, the values are more numerically similar.

It was observed that within the behaviour activities, a great part of time was spent in idleness $(65.5 \%)$. The results in the time of total idleness were similar as observed in other research with calves (VASCONCELOS, 1996). The time of total idleness, in calves, is higher than in adult animals, which is $42 \%$ approximately (CAMARGO, 1988). The time spent in laid down idleness was higher than when the calves were stood up idleness (Table 4), the inverse was observed by authors above cited. This behavior could probably occur due to housing being over a slatted floor.

The results of time spent in intake of solid feeds were 126.9 minutes ( $17.6 \%$ of time), with 46.7 and 82.2 minutes observed for the concentrate and hay, respectively. These values are similar to the values obtained by Weber (2002). Liquid intake occupied a minor part of evaluated activities, with a total of 17.8 minutes ( $2.47 \%$ of time). The time spent in rumination observed in this work (14.0\%) was superior at that verified in others trials, probably due a larger intake of hay. The intake of $161 \mathrm{~g} / \mathrm{calf} / \mathrm{day}$ was superior at the values found by Severo (1995), with values of $84 \mathrm{~g} / \mathrm{calf} / \mathrm{day}$.

During the experimental period, playing activity was not observed. Comparing different installations (individual x collective cages), Chua et al. (2002) found no differences between individual or paired-housed calves. The results confirmed the observations made by Keer \& Wood-Gush (1987) that calves raised in conventional housing would affect the expression of behavior due to the limitation of movement.

\section{CONCLUSIONS}

There were no differences among animal performance and behavior parameters when milk and/ or citric flavor agents are included in the diets of nursing dairy calves.

\section{REFERENCES}

ALBRIGHT, J. L. Nutrition and feeding calves: feeding behavior of dairy cattle. Journal of Dairy Science, Champaign, v. 76, p. 485-498, 1993. 
ATWOOD, S. B.; PROVENZA, F. D.; WIEDMEIER, R. D.; BANNER, R. E. Influence of free-choice vs. mixed ration diets on food intake and performance of fattening calves. Journal of Animal Science, Champaign, v. 79, p. 30343040, 2001.

BAUMONT, R. Palatabilitè et comportament alimentaire chez les ruminants. Production Animales INRA, Paris, v. 9, p. 349-358, 1996.

CAMARGO, A. C. Comportamento de vacas da raça holandesa em confinamento do tipo "free stall" no Brasil Central. 1988. 146 f. Dissertação (Mestrado em Zootecnia) - Escola Superior de Agricultura de Luiz de Queiroz, Piracicaba, 1988.

CHANDLER, P. T.; KESLER, E. M.; MCCARTHY, R. D. Effect of added dietary lard on growth and nutrient digestibility by calves 6 to 15 weeks old. Journal of Dairy Science, Champaign, v. 51, p. 1868-1872, 1968.

CHEEKE, P. R. Applied animal nutrition: feeds and feeding. New Jersey: Prentice Hall, 1991.

CHUA, B.; COENEN, E.; WEARY, D. M. Effects of pair versus individual housing on the behavior and performance of dairy calves. Journal of Dairy Science, Champaign, v. 85, p. 360-364, 2002.

CHURCH, D. C. El ruminante: fisiologia digestiva y nutrición. Zaragoza: Acribia, 1988.

GUILLOTEAU, P.; LE-HÜEROU-LURON, I.; QUILLET, J.; TOULLEC, R. Les sécretións digestives et leur regúlation chez le jeune veau préruminant. Production Animales INRA, Paris, v. 7, p. 85-95, 1994.

HAFEZ, E. S. E.; DYER, I. A. Desarrollo y nutricion animal. Zaragoza: Acribia, 1972.

KEER, S. G. C.; WOOD-GUSH, D. G. M. Comparison of the early behavior of intensively reared calves. Animal Production, Edinburgh, v. 45, p. 181-187, 1987.

LIZIEIRE, R. C.; CUNHA, D. N. F. V. da; MARTUSCELLO, J. A.; CAMPOS, O. F. Fornecimento de volumoso para bezerros pré-ruminantes. Ciência Rural, Santa Maria, v. 32, p. 835-840, 2002.
LEÓN, A. O. Desempenho de animais jovens da raça Holandesa criados sob diferentes épocas e dietas líquidas. 1994. 125 f. Dissertação (Mestrado em Zootecnia) Universidade Federal de Santa Maria, Santa Maria, 1994.

LUCCI, C. S. Bovinos leiteiros jovens. São Paulo: Nobel, 1989.

MATTHEWS, L. R. Measurement and scaling of food preferences in dairy cows: concurrent schedule and freeaccess techniques. New Zealand: University of Waikato, 1983.

MILLER, W. J.; CARMON, J. L.; DALTON, H. L. Influence of anise oils on the palatability of calf starters. Journal of Dairy Science, Champaign, v. 58, p. 1262-1270, 1958.

MORRILL, J. L.; DAYTON, A. D. Effect of whey on calf starter palatability. Journal of Dairy Science, Champaign, v. 57, p. 430- 434, 1974.

NOMBEKELA, S. W.; MURPHY, M. R.; GONYOU, H. W.; MARDEN, J. I. Dietary preferences in early lactation cows as affected by primary tastes and some common feed flavours. Journal of Dairy Science, Champaign, v. 77, p. 2393-2399, 1994.

SAS INSTITUTE. Statistical analysis's system user's guide. 2. ed. Cary, 1997. 456 p.

SCHALCH, F. J.; SCHALCH, E.; ZANETTI, M. A.; BRISOLA, M. L. Substituição do milho em grão moído pela polpa cítrica na desmama precoce de bezerros. Revista da Sociedade Brasileira de Zootecnia, Viçosa, v. 30, p. 280-285, 2001.

SEVERO, R. D. J. Desempenho de bezerros da raça holandesa em abrigos individuais e em bezerreiro convencional. 1995. 117 f. Dissertação (Mestrado em Zootecnia) - Universidade Federal de Santa Maria, Santa Maria, 1995.

SHUH, J. D.; WEGNER, T. N. Evaluation of a feed preference agent of dairy calves. Journal of Dairy Science, Champaign, v. 67, p. 1951-1953, 1979.

SUSIN, I.; MACHADO-NET, R.; PIRES, A. V.; PACKER, I. U. Desempenho de bezerros submetidos a diferentes dietas

Ciênc. agrotec., Lavras, v. 31, n. 3, p. 889-895, maio/jun., 2007 
líquidas e períodos de aleitamento. Revista da Sociedade Brasileira de Zootecnia, Viçosa, v. 17, p. 108-114, 1988.

VASCONCELOS, A. M. Desempenho de bezerros da raça Holandesa nascidos durante o período de outono/inverno submetidos a diferentes dietas líquidas e instalações. 1996. 93 f. Dissertação (Mestrado em Zootecnia) - Universidade Federal de Santa Maria, Santa Maria, 1996.
WEBER, A. Níveis crescentes de soro do leite na dieta líquida de bezerros da raça Holandês durante 0 aleitamento. 2002. 58 f. Dissertação (Mestrado em Zootecnia) Universidade Federal de Santa Maria, Santa Maria, 2002.

WEBER-NIELSEN, M. S.; BERGFELD, E. Critical perspectives in animal agriculture: a response. Journal of Animal Science, Champaign, v. 81, p. 2908-2911, 2003. 